\title{
Street Children's Problem in Getting Education: Economic and Parental Factors
}

\author{
Dr. Jamiludin, M. Hum. \\ Associate Professor, History Education Department, \\ Halu Oleo University, Indonesia \\ Dr. Darnawati, M. Pd. \\ Associate Professor, History Education Department, \\ Halu Oleo University, Indonesia \\ Waode Ade Sarasmita Uke, S. Pd. M. Pd. \\ Lecturer, English Department, \\ Halu Oleo University, Indonesia \\ Dra. Irawaty, M.Pd. \\ Senior Lecturer, Civic Education Department, \\ Halu Oleo University, Indonesia
}

Doi: $10.2478 / \mathrm{mjss}-2018-0010$

\section{Abstract}

Every child in this universe has the same right to get an education. However, some street children are not able to claim what they are supposed to obtain, such as the right to get a decent education and to play like other children, due to economic conditions which do not allow them to obtain their rights. The researchers attempt to facilitate them to develop their skills in English so that they can achieve their dreams. This research result indicates that most street children in Kendari undergo some financial and family problems which make them unable to afford education tuition fee. These problems appear to be the factors causing them to stop attending schools. Therefore, they prefer to be street children and work as street musicians, bearers, and parking attendants, for example to meet their day-to-day needs. Data were gathered through questionnaires and interviews. To analyze the data, qualitative method was employed.

Keywords: Street Children, Education, Economic, and Parental Factors

\section{Introduction}

The increasing number of street children in Kendari, especially around markets or shops in city center, might have been a concern for many people, including the authors. These children deserve a decent education to upgrade their knowledge and time to play and gather around with their friends, but due to financial concern, they could not obtain what they are supposed to get. Instead, they are more concerned about earning money to meet their family needs. Some street children make a living by working as bearers, parking attendants, street musicians, and even beggars.

Beside the above phenomenon, lack of knowledge about a significance of an education in 
their life is also one of the reasons for the lack of awareness to attain a decent education. One way to resolve this problem is to approach them personally. Personal approach can be initiated from social communities existing in Kendari. One of them is called KOJAK, a community for street children in Kendari. Volunteers from various fields manage this community to approach and educate street children in Kendari. This community has been in operation since 2008. Children in this community are from different education backgrounds, ages, and education levels, such as early childhood, elementary school, and junior high school. Some of them are still attending school, but others have dropped out.

As street children are the same as other children, they also have the right to obtain a decent education to get knowledge and to play around. However, street children are used to working rather than studying. According to the 1945 Constitution of Indonesia, Article 31, every citizen has the same right to obtain a decent education. Moreover, in the 1945 Constitution, Article 34, poor and abandoned children are reared by the state. Act number 20 of 2003, section 5 and line 1 states that every citizen has the same right to obtain high quality education. Furthermore, the 1945 Constitution, Article 34 also points out that compulsory education is the responsibility of the state, particularly public educational institutions, local government, and communities. This constitution becomes the authors' rationale to conduct teaching and learning activities for these street children. The researchers tried to conduct this research to investigate street children's problems to obtain a decent education.

\section{Literature Review}

Street children are those between 7 and 15 years old who live, work, and spend their time on the street or public places almost every day. They can be neglected, abandoned, or even emotionally and physically tied up with their family who lives together in the same house. In general, the characteristics of street children are: a. being in public places (street, markets, shops, amusement parks) for 3-24 hours in a day; b. having low level of education, i.e. having dropped out from schools or still being in primary school; c. originally coming from poor families (mostly urban people, some of them are only extended family); d. working in informal sectors.

Commonly, street children have the same problems in their daily life. Rafi, Ali, \& Aslam (2012, p.194) point out that problems faced by street children in their environment are often"... hunger, lack of adequate shelter, clothes, and other basic needs, as well as lack of (or limited) educational opportunities, health care, and other social services." More specifically, Hossain (2016)spells out the three most common problems, namely housing, food, and lack of jobs. Most street children have to take harmful jobs in exchange for food and shelter. Hai (2014, p.51) argues that "to keep the wolf of hunger away from their stomach many of them were obliged to embrace hazardous jobs". To make it worse, Myburgh, Moolla, and Poggenpoel (2015) argue that children living on the street might try to avoid the police by hiding and leaving the town for a week, a month or a year. Most street children do not go to school since there are some administration fees to be paid. Awatey (2014 , p. 171) says that "some street children really struggle for survival. When survival becomes an issue, long term strategies tend to be constrained by the need to fulfill the most basic necessities of life".

The importance of education is clearly stated in the 1945 Constitution Article 31, which indicates that every citizen has the right to get an education. Furthermore, the 1945 Constitution Article 34 also says that compulsory education is the responsibility of the state, particularly public educational institutions, local governments, and communities. In line with, Al-Dien (2009, p. 39) also argues that "the Convention on the Rights of the Child is clear: every child has the right to quality education that is relevant to his or her individual life and personal development". Based on the above, it can be implied that education plays significant role in life.

This motivates us to carry out community service activities by providing basic knowledge and motivation to street children as well as introducing teaching media to volunteers or teachers in Street Children Community in Kendari (KOJAK).

Some previous studies were conducted in relation to this study. First, Salokangas (2010) points out that through education, street children can become more useful and responsible in the 
society where they live. This is achieved by determining their task in the society, their basic human rights and responsibilities, respecting and assisting them in order to respect others as well. Second, Alam and Wajidi (2014, p. 56) recommend that "the process and techniques of educating the street children must be friendly and simple. These children would need more sympathy and affection than others". Kumalasari and Wijayanti (2013, p. 156) indicate "75\% of street children were boys and $72 \%$ of them went to elementary school and $56 \%$ of street children earn living as street musicians."

\section{Methods}

The method used in this study was qualitative method. In this study, the authors collaborated with a group of volunteers at the Street Children Community Kendari (KOJAK) who have the same perspective to develop the students' skill. The participants are 35 street children who always attend the meetings ( 22 participants were female and 13 were male) and 32 parents of them. The street children were $4-13$ years old. To take the sample for this study, the researcher applied purposive sampling. The research instruments in this study are questionnaire and interview. The questionnaire was analyzed by using descriptive statistics. The data was collected through administering questionnaire and conducting in-depth interviews with street children, volunteers, and KOJAK's boards. The questionnaire is divided into two parts. The first part includes questions relating to KOJAK. The second part is related to street children's activities. Meanwhile, parents were also given the questionnaire.

\section{Results and Discussion}

The increasing number of street children in Kendari is a social phenomenon that needs serious attention from various parties. This attention is not solely driven by the large number of street children, but also because of the situation in which the right of the poor street children is often violated. Given that "street children" refers to those aged less than 16 years old who spend most of their time on the street by doing particular activities to earn money in order to survive, the readers might get clear description of what street children are.

In addition, the characteristics of street children have been described earlier at the beginning of this paper. Based on the general characteristics, it is known that poverty is the main cause of their presence in the street. They come from low level education background and undergo financial problems. Therefore, they prefer to be street children and work as street musicians, for example, to meet their day-to-day needs.

Based on the interview result, the street children need affection and are willing to have a decent education. They want to be like other children. Kisirkoi (2016) comments that their needs are the same as those who grow up with a lot of care, love, affection, and protection from their parents. Street children hardly receive these kinds of things. They grow up in difficult circumstances and living conditions. The condition of street children in Kendari needs to be terribly concerned. Some of them have to work to obtain what they want. They often earn IDR20.000-50.000 in a day. Some of them use the money for good purpose, i.e. they hope the money can be saved for school equipment such as books, bag, uniform, and new shoes. Nonetheless, some of them waste the money they earn for negative acts such as buying cigarettes or glue which of course can harm their health. The involvement of street children in economic activities will adversely impact their personal development and future. This situation might not be beneficial for them and even tend to be an obstacle for their future, given that they are actually the future assets for the nation. Hence, the government should develop social community. Moreover, Omiyinka (2009, p.89)affirms "the solution to the problem of street children relies on the various societal structures and responsibilities (that is the family, community, policy, research, government, education and the street children)."

The main focus of social community development is social protection. Therefore, helping street children is not simply removing them from the street, but rather improving their quality of life or protecting them from exploitation. Referring to the principles of the social work profession, the policy and social protection programs include social assistance, education for encouraging skill and 
knowledge, and social welfare insurance. As a result, the social rehabilitation and empowerment are developed by right-based initiatives, considering serious fundamental rights of children in accordance with their best aspirations.

The alternative model for handling street children is classified into four types, namely:

1. Street-centered intervention, refering to the act of personally approaching the street children who was centered in the "street" where they usually work. The goal is to reach and serve the children in their immediate environment, i.e.in the street.

2. Family-centered intervention, refering to the idea of providing social assistance or family empowerment so as to prevent children from becoming street children or to attract street children to return to their families.

3. Institutional-centered intervention, refering to the intervention ideawhich concentrates on the institutions (nursing), both temporary (preparing reunification with their families) and permanent one (especially if the street children have no parents or relatives). This approach also includes a temporary shelter (drop in), "shelter" or "open house" that provide "homes and dormitories adaptation" for street children.

4. Community-centered intervention, centering on a community. Involving community development programs to empower or strengthen the capacity of social institutions in the community can establish networking with various institutions, both government agencies and civil society organizations. This approach also includes a Corporate Social Responsibility.

A social community called KOJAK which has existed since 2008 develops some programs based on the four types of street children intervention. It would be considered by the city as a model for handling street children in the city of Kendari.

Table 1 below presents the street children perception towards KOJAK as one of their places to get education.

Table 1. The result of questionnaire part I

\begin{tabular}{|c|l|c|c|}
\hline Part I: questions related to KOJAK & Yes & No \\
\hline No & tatements & 35 & 0 \\
\hline 1 & Are you happy about studying in KOJAK & 31 & 4 \\
\hline 2 & Do you always study in KOJAK every weekend? & 35 & 0 \\
\hline 3 & Do the volunteers and teachers teach you materials which are related to your education level? & 35 & 0 \\
\hline 4 & Do the volunteers and teachers ask you to play a game after class? & 29 & 6 \\
\hline 5 & Do the volunteers and teachers give you more explanation about your task at school? \\
\hline
\end{tabular}

Table 1 presents the street children's perception towards KOJAK as one of their places to get an education. Table 1 indicates that the street children are happy about studying in KOJAK. the interview result appears similar with the questionnaire that most children like studying in this community. Indeed, there are some reasons for this enjoyment. First, the volunteers are kindhearted. Second, the community allows them to join some competitions and events during the teaching and learning process in form of games. Third, the volunteers help them understand their tasks from school. Moreover, they also get some cookies after class. Hence, the street children become self-motivated to be active members in KOJAK to learn.

All children must study at school. The same case also applies to street children. However, they spend most of their time on the street to earn a living. They cannot access a decent education both formal and informal, including family education. The parents have important role to allow them to obtain education and to protect them.

Furthermore, society should not just remain silent about these neglected street children. We need to help the government, especially the local government of Kendari to handle this problem. Particularly, they need a helping hand from educators and volunteers to provide knowledge and skills for them. Al-Dien (2009, p. 43) demonstrates that "street education is a very effective way to support street children as it occurs at locations where they live. Educating street children involves helping them to acquire knowledge, skills and attitudes in specific areas of need." Abbasi (2013) 
argues that "organizations working with SWC engage the former "street children" (who were provided services in the past) as "street educators" who know their younger peers better and are able to convince them to attend school or learn some skills helpful to earn sustainable living."

Table 2. The result of questionnaire part II

\begin{tabular}{|c|l|c|c|}
\hline NO & Statement & Yes & No \\
\hline Part II: questions related to street children activities & 30 & 5 \\
\hline 1 & Are you a student? & 5 & 30 \\
\hline 2 & Are you dropout? & 20 & 15 \\
\hline 3 & Do you work on the street everyday? & 15 & 20 \\
\hline 4 & Do your parents ask you to work on the street? & 35 & 0 \\
\hline 5 & Do your parents ask you to study at home? & 25 & 10 \\
\hline 6 & Do you earn money IDR10.000- Rp 50.000 in a day? & 10 & 25 \\
\hline 7 & Are you happy about working on the street? & 20 & 15 \\
\hline 8 & Do you save your money for your school administration? & 10 & 25 \\
\hline 9 & Do you have any time to study at home? & 30 & 5 \\
\hline 10 & Do you have any time to play with your friends at home? & & \\
\hline
\end{tabular}

Table 2 outlines the result of questionnaire part 2 which is related to street children's activities. It is clearly seen that there are five students who do not attend school any longer. Some of them are happy about working on the street. They are working because not only their parents tell them to do so, but also because they are in position to earn living for their family. Most of them admitted that they do not have adequate time to study and play at home since they are very exhausted after studying at school and working on the street.

According to the interview result, there are some factors influencing street children to work, including both internal and external ones. Some internal factors are; a) they had low interest in studying at school. They thought that school is such a waste because school did not provide any benefit for them compared to working on the street as the latter allows them to get money to pursue what they want; b) they got neither appreciation nor encouragement from school that they were able to attend other examination to just pass; and c) They have some future ideas such as becoming a doctor, teacher, and civil servant, but they did not get enough support and knowledge for those ideas.

Some external factors include (a) socio-economic conditions. Most parents work as construction workers, security guards, motorcycle taxi drivers, cleaning service and some who did not have regular job with low incomes. The figure below indicates the parents' perception.

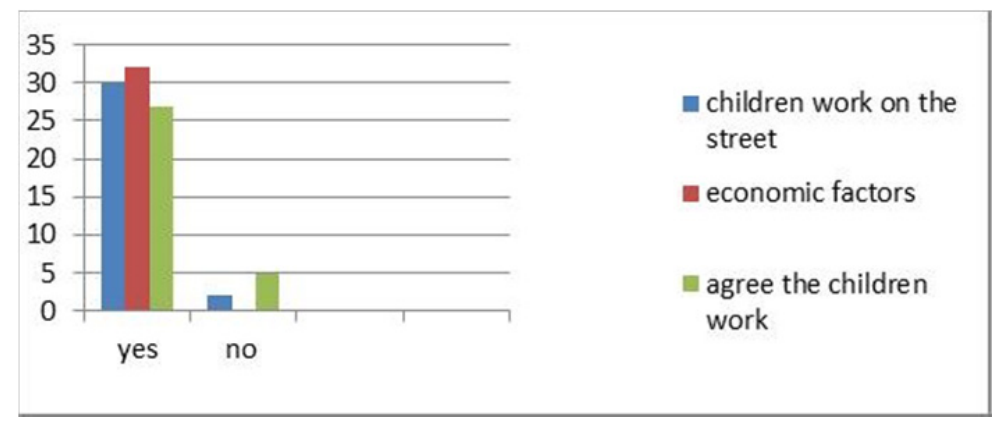

Figure 1. The result of questionnaire of the street children's parents

Figure 1 indicates the parents' perception. It shows that the highest score is that street children's parents had financial concerns; hence they asked and agreed that their children work on the street. The lowest one is the children work on the street voluntarily. Furthermore, (b) some street children 
have broken family, the result of which is a lack of attention and focus as well as distraction. They then do something negative like smoking or other negative acts. In addition, (c) some parents thought that education is less important because attending school is such a waste of money and energy, and that education is only for those who can afford it. The government seemed not to give a hand to the poor family. Children cannot help their family if they choose to attend the school, and they have low parents' education level.

Apart from the factors above, street children who got off working on the streets are willing to go to school to make their ideas come true.

\section{Conclusions and Recommendations}

Based on the above discussion, it can be concluded that:

1. The education problem is still regarded as the responsibility of the government and schools.

2. Cultural factors and lack of parents' attention to the importance of education cause street children to help their parents work for a living, leading them todropout. The government needs to conduct an education campaign in the form of socialization and face-to-face dialogue.

3. Socio-economic factoris also one of the significant factors. Therefore, the government should provide scholarships for street children.

4. Some street children still want to attend school to get a decent education. English is one of notable skill which is important for their personal development.

\section{Acknowledgement}

This research was supported partially by Street Children Community Kendari (KOJAK). We would like to thank our colleagues from Halu Oleo University who provided insight and expertise that greatly assisted this research.

\section{References}

Abbasi, A. (2013). An Explication of the Paradox of Street Working Children (SWC) with Special Reference to Pakistan. International Journal of Humanities adn Social Science, 3(20), 51-60.

Al-Dien, M. M. Z. (2009). Education for Street Children in Egypt: The Role of Hope Village Society. Journal of Contemporary Issues in Education, 4(1), 37-56.

Alam, S., \& Wajidi, M. A. (2014). Refining the Street Children with Education IOSR Journal of Research \& Method in Education 4(3), 54-57.

Awatey, S. (2014). Assessing the Effects of Streetism on the Livelihood of Street Children : A Case Study of Kumasi (in Ghana). Research on Humanities and Social Sciences, 4(9), 165-174.

Hai, A. M. (2014). Problems Faced by the Street Children: A Study on Some Selected Places in Dhaka City, Bangladesh. International Journal of Scientific \& Technology Research 3(10), 45-56.

Hossain, S. A. (2016). Socio-Economic Status of the Street Children. International Journal of Social Work, 3(1), 42-49.

Kisirkoi, F. K. (2016). Education Access and Retention for Street Children: Perspectives from Kenya. Journal of Education and Practice, 7(2), 88-94.

Kumalasari, P. P. W., \& Wijayanti, D. Y. (2013). elf-concept of Street Children Teenagers in Central Semarang.Journal of Soul Nursing, 1(2), 156-160.

Myburgh, C., Moolla, A., \& Poggenpoel, M. (2015). The Lived Experiences of Children Living on the Streets of Hillbrow. Curationis, 38(1), 8.

Omiyinka, F. O. (2009). Social Networks and Livelihood of Street Children in Ibadan, Nigeria. International Journal of Sociology and Anthropology, 1(5), 082-089.

Rafi, S., Ali, M., \& Aslam, M. A. (2012). The Problem of Street Children: Case Study of Sargodha City. American International Journal of Contemporary Research, 2(2), 194-197.

Salokangas, R. (2010). The Successes and Challenges of Reintegrating Street Children through Nonformal Education in Maputo City, Mozambique. University of Tampere. 